\title{
Gedagtes oor die Afrikaanse Vaktaal vir Meganiese Ingenieurswese
}

\author{
H.G. Denkhaus \\ Departement Meganiese Ingenieurswese, Universiteit van Pretoria, 0002
}

Die ontwikkeling van ' $n$ taal is ' $n$ dinamiese proses en enige lewende taal hou maar aan om te ontwikkel, d.w.s. te verander. Dit geld veral vir die tegniese vaktaal wat as gevolg van die snelle ontwikkeling van die tegnologie gedurig nuwe begrippe moet huisves. Dit is dan ook die taak van die ingenieurs en wetenskaplikes wat die eerste met nuwe begrippe en uitdrukkings in aanraking kom, om hulle uit 'n vreemde taal waar hulle geskep is, in die eie taal oor te dra.

Hier kom die tegniese woordskepper nou te staan voor twee alternatiewe waartussen hy 'n gangbare en gesonder middelweg moet vind. Die een alternatief is om 'n woord te skep wat beskrywend is en volkome by die karakter van die eie taal pas, en die ander is om die vreemde woord, miskien met sekere wysigings ten opsigte van spelreëls, eenvoudig oor te neem.

Die rede vir die laasgenoemde alternatief is die strewe om tegniese vaktale so internasionaal verstaanbaar te maak as wat dit onder omstandighede moontlik is, sodat Afrikaanse artikels, verhandelings, referate en dies meer - of dan die byskrifte van grafieke, sketse en foto's - ook deur buitelanders begryp kan word sonder dat hulle Afrikaans magtig hoef te wees.

As ' $n$ voorbeeld van hierdie benadering kan genoem word dat op 'n sekere tydstip daaraan gedink is om 'n begrip uit die materiaalmeganika wat hedendaags bekend staan as "proporsionaliteitsgrens", te vertaal met "eweredigsheidsgrens". Dit is natuurlik 'n suiwer Afrikaanse woord wat uit suiwer Germaanse elemente bestaan. Nogtans is dit te verwelkom dat "proporsionaliteitsgrens" deurgedring het, want dit is "proportionality limit" in Engels en "limit de proportionalité" in Frans en selfs in Duits is dit "Proportionalitätsgrenze", alhoewel die term "Verhältnisgleichheitsgrenze" moontlik is en 'n suiwer Duitse woord sou wees.

Uit ' $n$ stelling in die vorige paragraaf kan miskien afgelei word dat ' $n$ suiwer Afrikaanse woord uit Germaanse elemente moet bestaan. Dit is natuurlik nie so bedoel nie, want - alhoewel Afrikaans sekerlik primêr 'n Germaanse taal is - beteken dit nie dat dit nie verryk is deur sekere vreemde woord nie, soos bv. "baie" of "piering" wat van Maleise of Oos-Indiese oorsprong is. Daar is ook 'n sterk Franse - dus Latynse, of Romeinse - element in Afrikaans teenwoordig. Niemand hoef hom daaroor te bekommer nie, want die assimilasie van vreemde woorde is 'n algemene verskynsel in alle tale. Die woord "neus" byvoorbeeld (nose in Engels, Nase in Duits, nez in
Frans) is van Arabiese oorsprong, soos ook die woord "alkohol" en "algebra" en andere. Dus, om terug te kom na die vorige paragraaf, die term "proporsionaliteitsgrens" is heel aanvaarbaar.

Alhoewel die verwydering van vreemde woorde uit ' $n$ taal, veral as daar toepaslike en mooi woorde in die eie taal bestaan, besonder wenslik is, moet daar tog gewaak word teen die belaglike oordrywing van hierdie strewe. Om weer 'n Duitse voorbeeld aan te haal, kan genoem word dat in die tydperk tussen die twee Wêreldoorloë toe die Duitsers nog nasionaalgesind was, die strewe bestaan het om die taal van vreemde woorde te suiwer. Daar was wel belaglike voorstelle, soos om bv. die woord "Lokomotive" met "Ziehe" (= trekding) en "Elektrische Lokomotive" met "Bernziche" te vervang ("Bern" van "Bernstein" - barsteen vir alle woorde met "elektries", aangesien statiese elektrisiteit gedemonstreer kan word deur barsteen te vryf). Aan die ander kant was daar baie gesonde voorstelle wat nie net posgevat het nie, maar selfs aanleiding gegee het tot nuwe aanvaarbare en aanvaarde woordskeppings. 'n Tipiese voorbeeld is die vervanging van die Franse woord "trottoir" vir sypaadjie deur "Bürgersteig" (steeg vir die burger). Dit het gelei tot die vervanging van "peron" vir platform deur "Bahnsteig" (steeg vir spoorwegpassasiers), en vandag lees die reisiger by Duitse lughawens algemeen die woord "Flugsteig" (steeg vir vliegtuigpassasiers).

Die woordontwikkeling Bürgersteig - Bahnsteig - Flugsteig wat volkome in die Duitse taal ingeburger is sodat niemand meer praat van "trottoir" of "peron" ens. wat sowat vyftig jaar gelede nog gebruiklike woorde was nie, laat 'n mens wonder hoekom ons in die Afrikaanse taal nog altyd aan die verskriklike woord "enjin" kleef, terwyl motor'n beter beskrywende woord is. "Motor" is nou wel 'n Latynse wood en beteken "beweger", maar dit word in baie tale verstaan en is beskrywend. "Enjin" is egter brabbel-Engels en wil die skepping van 'n "engineer" beskryf, waarby vergeet word dat 'n ingenieur ook ander dinge, bv. werktuigmasjiene, pompe, brûe en dies meer skep. Laat ons nou teen hierdie agtergrond 'n paar vertalings krities bestudeer:

1. Die beroepsrigting wat hedendaags bekend staan as "meganiese ingenieurswese" was in die vyftigerjare nog dikwels na verwys as "werktuigkundige" ingenieurswese. Daar was 'n Hoof Werktuigkundige Ingenieur by die Spoorwee en 'n Departement Werktuigkundige Ingenieurswese by 
die Universiteit van Stellenbosch. Nou is "werktuigkundig" wel 'n suiwer Afrikaanse woord van Nederlands-Duitse oorsprong. Dit omskryf die vak egter nie omvattend genoeg nie, want die betrokke ingenieur is kundig van meer dinge as net werktuie. Toe het die beter beskrywende woord meganiese ingenieurswese deurgedring. Dit is afkomstig van die Griekse "mechanike techne" (masjienkuns). Verder is die vak ook in die Engels-Amerikaanse taalbereik bekend as "mechanical engineering" en ter wille van internasionale uniformiteit behoort ons met die keuse van die woord "meganies" tevrede te wees. In Duits is dit egter altyd "Maschinenwesen" wat regstreeks na die Latynse woord (machina) teruggaan.

2. Daar word 'n probleem ondervind met die vertaling van die Engelse woord "random". Tegniese woordeboeke* vertaal dit met "willekeurig, toevallig, ewekansig". Nou laat ons dit toepas om die begrip "random vibrations" te vertaal. Hulle is sekerlik nie willekeurig of ewekansig of toevallig nie. Wat met "random vibrations" bedoel word, word volgens my mening beste beskryf deur "toevalbeheerde vibrasies", want dit is inderdaad die toeval wat hulle beheer en hulle staan as ' $n$ groep teenoor 'n ander groep naamlik "voorspelbare vibrasies" wat of "ekstern beheerd" of "selfbeheerd" of "vry" mag wees.

3. Woordeboeke* gee die keuse tussen "vibrasie" en "trilling" as vertaling vir die Engelse "vibration" (Duits: "Schwingung"). Trilling is 'n besonder mooi en suiwer Afrikaanse woord wat die sensasie van 'n vibrasie goed beskryf. Nogtans moet "vibrasie" voorkeur geniet teenoor die oorweldigende massa literatuur wat onder die kodewoord "vibration" gevind word. Selfs die Duitsers verstaan wat bedoel word as iets "vibrier".

4. In die moderne ingenieurswese word daar dikwels gebruik gemaak van die begrip wat in Engels bekend staan as "root mean square" en afgekort "r.m.s." Afrikaanse woordeboeke" vertaal dit met "wortel van die gemiddelde kwadraatwaarde" en afgekort met "w.g.k." Sonder twyfel is die Afrikaanse woord beter beskrywend as die Engels. Die vraag ontstaan egter of ons by die afkorting "w.g.k" moet bly of tog maar (net vir die doel van afkorting die "r.m.s." moet oorneem omdat dit in die internasionale vakliteratuur wyd versprei is. Ek wil daarvoor pleit. Ons gebruik $\log$ in Afrikaans die woord "laser" wat niks anders is as die afkorting van die Engels-Amerikaanse woord "light amplification by stimulated emission of radiation" nie. Selfs die Duitsers gebruik dit, alhoewel hulle ook die mooi woord "Lichtverstärker" daarvoor het, wat ook Afrikaans as "ligversterker" goed te pas sal kom.

5. Daar bestaan twee metodes om vibrasies te

- H.J. Terblanche: Engels-Afrikaanse Tegniese Woordeboek, 3e uitgawe, Nasou, Elsiesrivier/Kaap 1976. bekamp, naamlik deur demping en deur "delging". Nou is die voorgestelde term alreeds gebruik, naamlik "delging", wat beteken dat die vibrasie sonder energieverlies verminder of volkome gedelg word, terwyl demping altyd met energieverlies, d.w.s. omsetting in warmte, verbonde is. Die Engelse term vir wat hier as "vibrasiedelger" beskryf word, is "vibration absorber" en woordeboeke ken geen Afrikaanse ekwivalent nie. Die voorgestelde Afrikaanse term word afgelei van die Duitse "Schwingungstilger" wat die proses treffend beskryf, want daar word niks "geabsorbeer" nie.

6. Breukmeganika is 'n vakgebied wat oor die afgelope dekades sterk op die voorgrond van belangstelling getree het. Dit het o.a. meegebring dat sekere terme soos breuk, swigting, barsting en dies meer, wat gewoonlik as sinoniem gebruik word, nouer gedefinieer moet word. Die volgende tabel is 'n voorstel vir hierdie skerper definisies van 'n paar begrippe uit die breukmeganika.

Afrikaans Engels Definisie

swigting failure Algemene term vir die oorgang van een materiaaltoestand in 'n ander.

kraking cracking Oorgang van die soliede toestande na een waar krake gevorm is, maar waar die materiaal nog saamhangend bly.

vloeigrens yield limit Oorgang van 'n oorheersend elastiese-tydonafhanklike na 'n oorheersend plasties-tydafhanklike vervormingsgedrag.

breuk fracture Oorgang van 'n soliede of gekraakte toestand na een waar die oorspronklike struktuur in twee of meer stukke verdeel is.

breek- breaking Hoogste spanning wat die

sterkte strength struktuur kan weerstaan sonder om te breek (d.w.s. om in twee of meer stukke te verdeel).

barsting rupture Oorgang van 'n soliede, gekraakte of selfs gebreekte toestand na een van volkome vergruising, sodat die oorspronklike struktuur nie meer herkenbaar is nie.

7. Die woorde wat in verband met termiese energie in Afrikaans gebruik word, is "hitte" en "warmte" en daar word dikwels gestry of dit, byvoorbeeld, "hitteoordrag" of "warmteoordrag" moet wees. Nou beskryf die woorde "warm" (en "koud") net temperatuurverskille, maar nie die energievlak nie, en derhalwe is ' $n$ mens geneig om liewers "hitte" as die woord in verband met terme van termiese energie te aanvaar. Daar moet toegegee word dat "hitte" eintlik net die ekstreem van 
"warmte" is, maar "warm-koud" beskryf 'n temperatuurverskil beter as "vurig (Engels hot)" yskoud" dit sou kon doen. Verder gebruik die Engelse nou altyd die woord "heat" en die Afrikaners praat ook van "hitte" (hulle het dit nie oorgeneem nie, want dis 'n ou Germaanse woord, in Duits "Hitze"). Dus, kom ons sê "hittevoortplanting, hitteoordrag, hittekapasiteit" ens.

8. Twee besonder goed beskrywende Afrikaanse woorde wat voorgestel word is die vertaling van "Hefskroewer" vir die Engelse "helicopter" en "draskroewer" vir die Engelse "autogyro", want die verskil tussen die twee is dat die hefskroewer (helicopter) se lemme aangedryf word om hefkrag aan die vliegtuig te verleen terwyl die draskroewer (autogyro) net roteerbare lemme het wat (op die manier van ' $n$ windmeule) roteer en daardeur (as roterende vlerke) die vliegtuig in die lug hou (d.w.s. dra). "Skroewer" is afgelei van "skroef" en beskryf die beweging van die lemme relatief tot die aarde.

Die genoemde voorbeelde toon dat by die skepping van tegniese vaktaal dit wel moontlik is om die genoemde middelweg tussen woordskepping in die eie taal in die kritieklose oorname van vreemde woorde te vind. 